\title{
The Effect of Microclimates in the Aeolian Sand Environment at the Mogao Grottoes, China
}

\author{
Guo Shuai $\mathrm{Li}^{1,2,3}$, Jian Jun $\mathrm{Qu}^{4,5,6, *}, \mathrm{Xu} \mathrm{Zhi} \mathrm{Li}^{1}$, and Wan Fu Wang ${ }^{7}$ \\ ${ }^{1}$ Technology and Engineering Center for Space Utilization, Chinese Academy of Sciences, Beijing, China \\ ${ }^{2}$ Institute of Remote Sensing and Digital Earth Chinese Academy of Sciences, Beijing, China \\ ${ }^{3}$ College of Resources and Environment, University of Chinese Academy of Sciences, Beijing, China \\ ${ }^{4}$ Dunhuang Gobi and Desert Research Station, Cold and Arid Regions Environmental and Engineering \\ Research Institute, Chinese Academy of Sciences, Dunhuang, China \\ ${ }^{5}$ Key Laboratory of Desert and Desertification, Cold and Arid Regions Environmental and Engineering \\ Research Institute, Chinese Academy of Sciences, Lanzhou, China \\ ${ }^{6}$ Gansu Center for Sand Hazard Reduction Engineering and Technology, Lanzhou, China \\ ${ }^{7}$ The Conservation Institute of Dunhuang Academy, Dunhuang, China
}

Received 30 June 2012, accepted 9 October 2012

\begin{abstract}
To study the micro-meteorological effects of different underlying surfaces of structures to protect the Mogao Grottoes, we analyzed basic meteorological measurements collected at weather stations located in front of the grottoes, on top of the grottoes and in the artificial Gobi. The results show that the shelterbelts in front of the grottoes have a heat-retaining effect. The profile of average daily solar radiation in front of the grottoes forms a sharp peak and the profile in the Gobi forms a parabola, but these patterns vary in different seasons. The artificial Gobi was more susceptible to extremes in temperature and had a faster response and wider response range to ground temperature. The average monthly air temperature, average monthly relative humidity, and the average wind speed in the artificial Gobi tend to first decrease and then increase with measurement height.
\end{abstract}

Key words: Air temperature, Ground temperature, Relative humidity, Wind speed, Solar radiation, Atmospheric pressure, Mogao Grottoes Citation: Li, G. S., J. J. Qu, X.Z. Li, and W.F. Wang, 2013: The effect of microclimates in the aeolian sand environment at the Mogao Grottoes, China. Terr. Atmos. Ocean. Sci., 24, 89-105, doi: 10.3319/TAO.2012.10.09.02(A)

\section{INTRODUCTION}

The Mogao Grottoes lie in the steep cliffs of Mount Mingsha in the Dunhuang area of Gansu Province, China. This unique world cultural legacy suffers from wind erosion year around. Protective measures against aeolian sand damage have included shelterbelts and an artificial Gobi, with the former as a buffer zone used to prevent wind abrasion of the rock walls, and the latter made by paving gravel that replaced some of the original gravel that formed the natural landscape of the Mogao Grottoes (Fig. 1).

Different underlying surfaces have different local effects on environments with aeolian sand. Research on the effects of local meteorology have mainly focus on air temperature (Marshunova 1961; Charney 1975; Chou et al.

\footnotetext{
* Corresponding author

E-mail:qujianj@lzb.ac.cn
}

1981; Parungo 1996; Wang et al. 1998; Bounoua et al. 2002; Zeng et al. 2002; Golitsyn et al. 2004; Zhong et al. 2010), ground temperature (Zhong et al. 2010), relative humidity (Zhong et al. 2010), solar radiation (Marshunova 1961; Parungo 1996; Kukharets et al. 2000; Golitsyn et al. 2004; Wang et al. 2009; Wu et al. 2010), atmospheric pressure (Wang et al. 1998; Hara et al. 2006; Kaczenskya et al. 2008; Pankova 2008; Lee et al. 2010; Yu et al. 2010), and wind speed and direction (Ishizuka et al. 2005; Zhang et al. 2008; Zhong et al. 2010). The dramatic variations in temperature and relative humidity around the grottoes might influence the air temperature inside the grottoes and surface temperature on the murals by heat transfer. The expansion of the mural with an increase in temperature and contraction with a decrease in temperature, is not ideal for long-term preservation of the murals. The increase in relative humidity can 


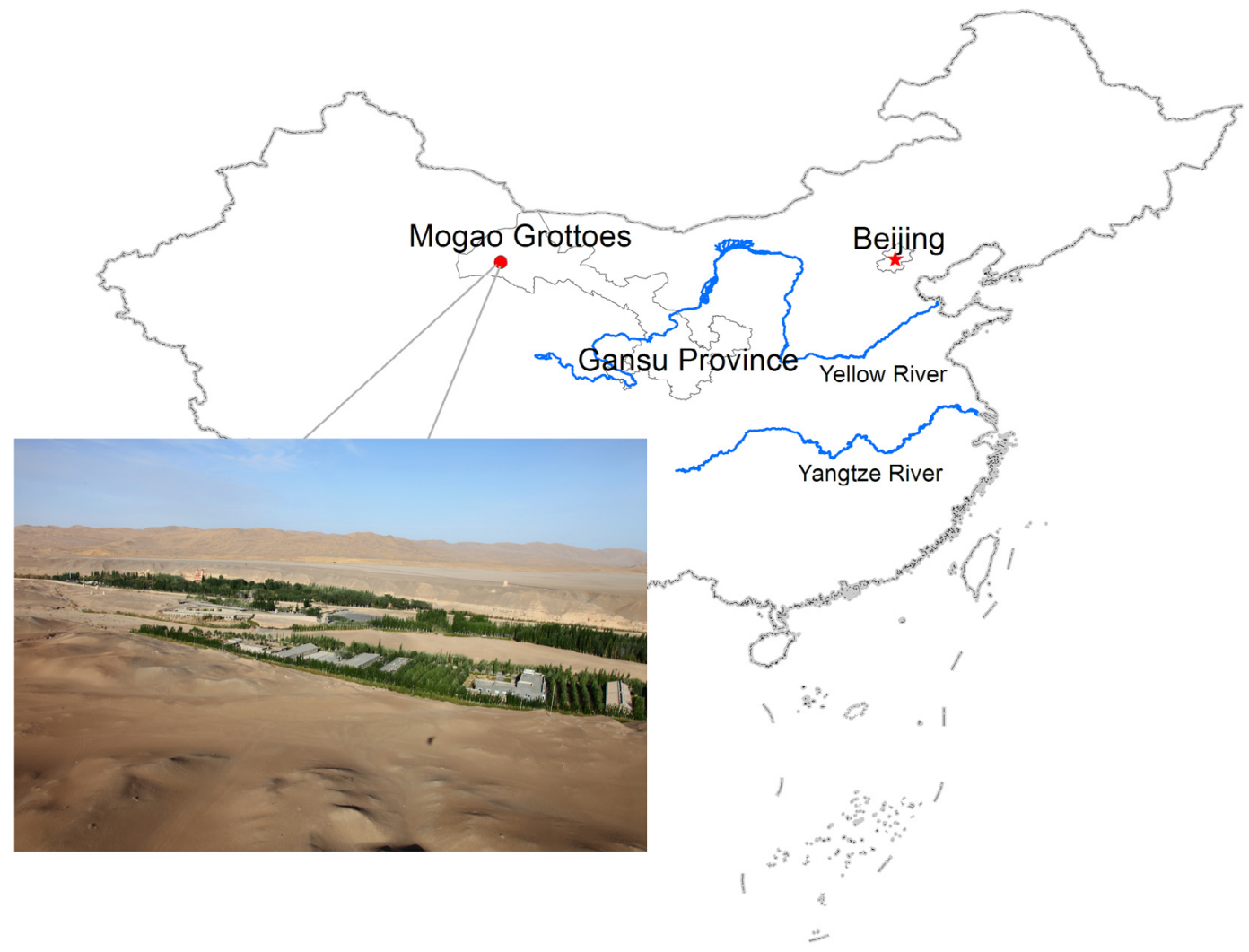

Fig. 1. Geographical location of the Mogao Grottoes.

cause condensation and/or salt deliquescence on the murals (Li et al. 2012b). The wind can cause sand abrasion, and even bury the grottoes ( $\mathrm{Li}$ et al. 2012a). Solar radiation can also affect color of the murals or cause fading, besides making the grottoes warmer and drier. Changes in atmospheric pressure can force air with much moisture to flow around in the grottoes and damage the murals over and over ( $\mathrm{Li}$ et al. 2012b).

During 2005 to 2009 the average annual temperature in the Mogao Grottoes area was $10.5^{\circ} \mathrm{C}$; the average annual relative humidity was $28.1 \%$; and average annual rainfall was $36.5 \mathrm{~mm}$ in this arid desert climate zone (Li 2012). Ample research has been conducted on the different underlying surfaces (Marshunova 1961; Zilitinkevich and Chalikov 1968; Lykosov and Gutman 1972; Zhang 1995; Kukharets et al. 2000; Golitsyn et al. 2004; Gorchakov et al. 2004; Jin et al. 2004; Zhong et al. 2010) as well as on natural Gobi (Parungo 1996; Wang et al. 1998, 2009; Qu et al. 2001; Ishizuka et al. 2005; Liang et al. 2005; Hara et al. 2006; Kaczenskya et al. 2008; Pankova 2008; Zhang et al. 2008; Lee et al. 2010; Yu et al. 2010). However, the artificial Gobi has not been sufficiently studied. The shelterbelts in front of the grottoes, the hummocks on top of grottoes, and the artificial Gobi are the three underlying surfaces investigated in this study.

Because the artificial Gobi and the shelterbelts near the Mogao Grottoes are important parts of the aeolian sand protection system, studies on their meteorological effects will benefit the preservation of the grottoes. Micrometeorological changes have resulted from the various changes to the original local landforms. Understanding micrometeorological effects of the three types of underlying surfaces may explain local changes in the environment surrounding the grottoes.

\section{DATA AND METHODS}

In 1989 the Dunhuang Cultural Research Institute set up an automatic weather station $\left(40^{\circ} 02^{\prime} 15.3^{\prime \prime} \mathrm{N}, 94^{\circ} 48^{\prime} 11.6^{\prime \prime} \mathrm{E}\right.$, $1378 \mathrm{~m}$ ) on top of Grotto 96 with the collaboration of the Getty Conservation Institute (USA). In 1999, in collaboration with Osaka University (Japan), an automatic weather station (4002'18.6”'N, 9448'14.3"E, elevation $1338 \mathrm{~m}$ ) was sited in front of Grotto 72 . These weather stations are both used for continuous monitoring of the surrounding environment. In 2003, another automatic weather station $\left(40^{\circ} 02^{\prime} 39.7\right.$ 'N, 9447'50.7'E, elevation $1367 \mathrm{~m}$ ) (Getty Conservation Institute) was set up in the artificial Gobi for monitoring micrometeorological effects after changes to the original Gobi (Fig. 2).

For this study, the weather station in front of the grottoes, the weather station on top of the grottoes and weather 


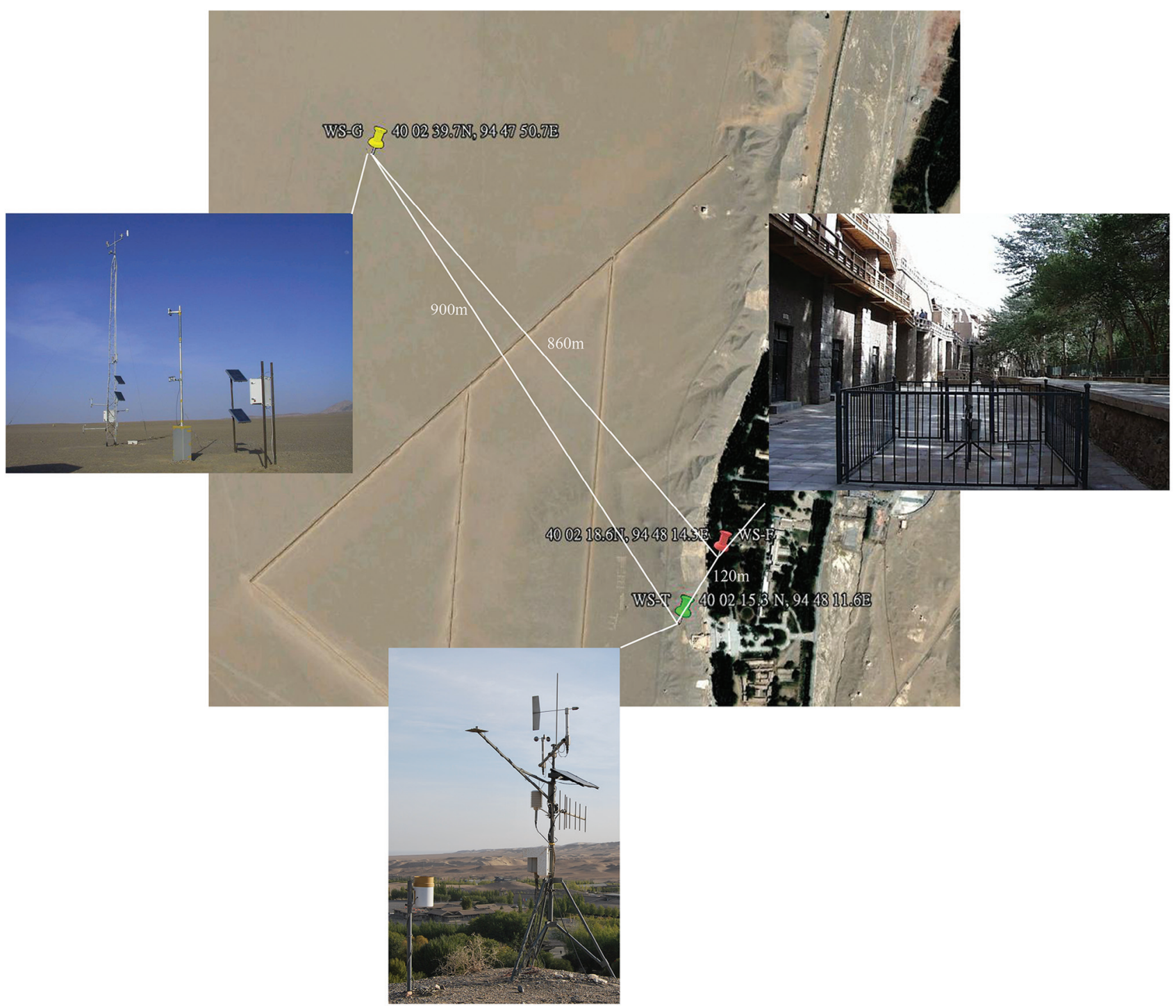

Fig. 2. The location of weather station in the study area.

station on the Gobi are referred to as WS-F, WS-T, WS-G, respectively. The stations located at the front of grottoes, on top of grottoes and in the artificial Gobi are referred to as IFG, OTG and IAG, respectively. The shelterbelts adjacent to WS-F are mainly Populus alba L. var. pyramidalis Bunge, Populus alba L., Ulmus pumila L., Fraxinus chinensis Roxb. and Platycladus orientalis (L.) Franco et al. The soil type near WS-F is sediment deposited by floods of differing ages, consisting of sand loam soil $(0-50 \mathrm{~cm})$, sandy soil (50 $80 \mathrm{~cm}$ ), coarse sand soil with some gravel $(80-120 \mathrm{~cm}$, existing $10 \mathrm{~cm}$ clay soil in some local areas) and sandy soil $(>120 \mathrm{~cm})$. The soil mantle next to WS-T consists of small gravel $(0-1 \mathrm{~cm})$, with the coverage $23.53 \%$ and the roughness 0.204 ; the surface soil near WS-G consists of medium gravel $(2-4 \mathrm{~cm})$ and big gravel $(4-6 \mathrm{~cm})$ with the coverage $30-40 \%$ and the roughness 0.277 ( $\mathrm{Li} 2012)$. The average land surface albedo of Dunhuang oasis (0.17) is referred as the albedo at WS-F, the Gobi and desert area is referred to the albedo at WS-T and WS-G (0.21 - 0.24) (Zhang et al. 2005).

Monitoring data from 2005 to 2009 such as air temperature, ground temperature, relative humidity, wind speed, solar radiation, and atmospheric pressure were analyzed for this study. WS-T is a Campbell automatic weather station, with temperature and relative humidity monitored by an HMP45C transducer, wind speed by a 014A transducer, and solar radiation by an AV-19Q PAR and LI190SB PAR quantum sensor. WS-F is a HOBO weather station, with temperature and relative humidity monitored by an S-THAM002 transducer, wind speed by a S-WCA-M003 transducer, solar radiation by an S-LIA-M003 quantum sensor, and atmospheric pressure by S-BPA-CM10 transducer. At WS-F data are collected every 15 minutes. WS-G is a micro-climate automatic observation system with five layers, 
$10 \mathrm{~m}$ high. The observation height at WS-T and WS-F is $2 \mathrm{~m}$, but wind speed, air temperature, and relative humidity of WS-G are monitored by the gradient method, which measures the variables at different heights. The heights at WS-G are 1, 2, 4 and $10 \mathrm{~m}$. To compare among the stations, the data collected at 24-hour intervals are used as the values for the variables. For comparison of WS-F, WS-T and WS-G, the variables measured at $2 \mathrm{~m}$ height were used (the same as those of WS-F and WS-T).

\section{RESULTS AND ANALYSIS}

\subsection{Air Temperature}

The average monthly mean air temperatures at IFG and OTG were similar to those at IAG. Considering that the elevation difference between these sites is less than $40 \mathrm{~m}$, the small elevation difference between the stations can be neglected for the comparisons of air temperature. In January the average air temperature at IFG was $-9.46^{\circ} \mathrm{C}$, OTG $-10.09^{\circ} \mathrm{C}$, and IAG $-10.29^{\circ} \mathrm{C}$, indicating that the original Gobi environment experiences cooler temperatures. The maximum temperatures in July were $25.49^{\circ} \mathrm{C} \mathrm{IFG}, 25.64^{\circ} \mathrm{C}$ OTG, and $25.94^{\circ} \mathrm{C}$ IAG. As shown in Fig. 3, the average air temperature IAG suddenly declined in August; the average air temperature was $23.1^{\circ} \mathrm{C}$ in August and dropped to $12.88^{\circ} \mathrm{C}$ in September, and was about $13.12^{\circ} \mathrm{C}$ in October. Because the decreased amplitudes for air temperature in September 2008 were larger than during other periods, the average air temperature during 2005 - 2009 was lower. Because shelterbelts at IFG retained heat and influenced WS-T, the average air temperatures at IFG and OTG in September were about $7^{\circ} \mathrm{C}$ higher than that at IAG. Figure 4 shows that the average air temperature increased during 2005 - 2009. The inter-annual variability in the artificial Gobi was higher than at OTG and IFG. Compared with the average monthly air temperature at IFG and OTG, the artificial Gobi appears to be more susceptible to extremes of air temperature and can be used as an indicator of dramatic changes in air temperature.

Figure 5 shows that the difference between the average daily air temperatures at IFG and OTG, and IAG was less than $1{ }^{\circ} \mathrm{C}$ during all seasons. The average daily air temperature at IFG from 9 am to $11 \mathrm{pm}$ in spring was higher than that in autumn (lower from 0 to $8 \mathrm{am}$ ). The average daily air temperature at OTG from 4 to 7 am and at 12 am was higher than that in spring (lower at other times). The average daily air temperature at IAG from 6 to 7 am was higher than that in spring (lower at other times). The minimum average daily air temperature at IFG, OTG and IAG in summer and winter occurred at 7 and $9 \mathrm{am}$, respectively. The maximum of average daily temperature at OTG and IAG in summer, autumn, and winter occurred at $5 \mathrm{pm}$ (Table 1).

The analysis of gradient observations at IAG $(1,2,4$ and $10 \mathrm{~m}$ ) showed that the average monthly air temperature in that area initially decreases and then increases with increasing height. Average monthly air temperatures at heights of 4 and $2 \mathrm{~m}$ at IAG in October, April, July and January decreased in the order shown in Fig. 6.

\subsection{Ground Temperature}

The differences in specific heat and configurations in the shelterbelt (IFG), in the natural hummocks (OTG), and IAG cause variations in ground temperature. Figure 7 shows

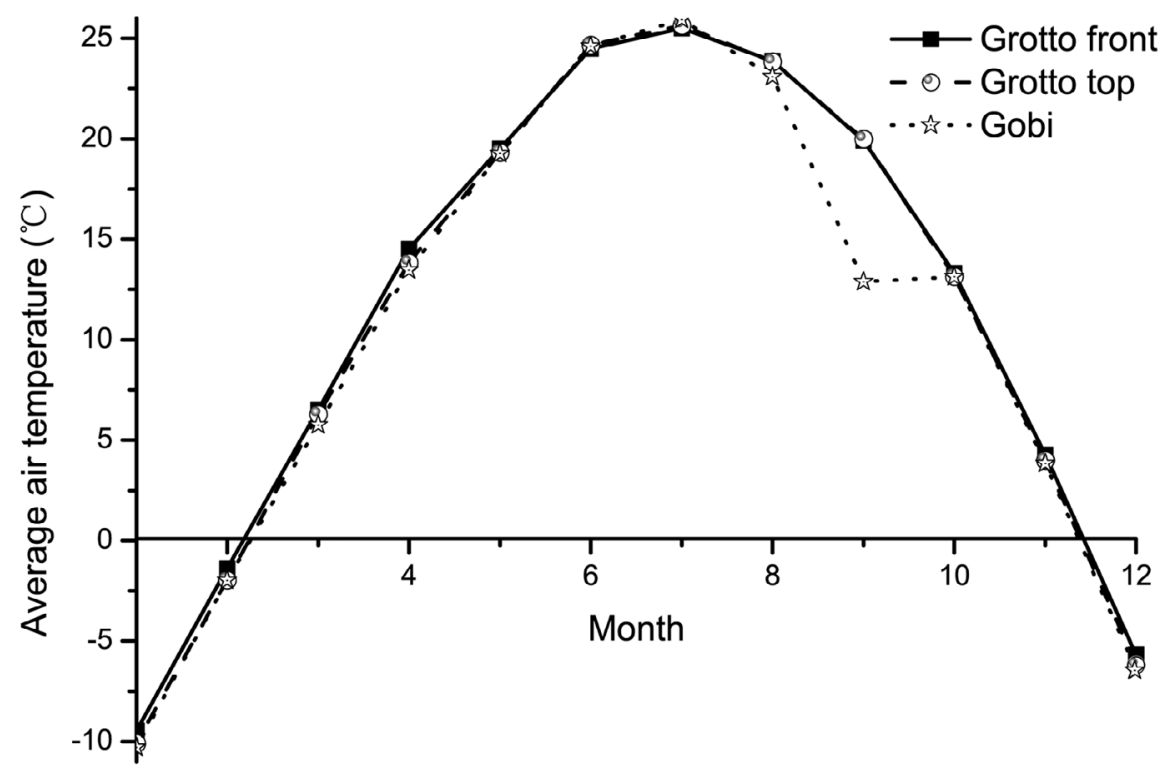

Fig. 3. Monthly variation of average air temperature at IFG, OTG and IAG during 2005 - 2009. 


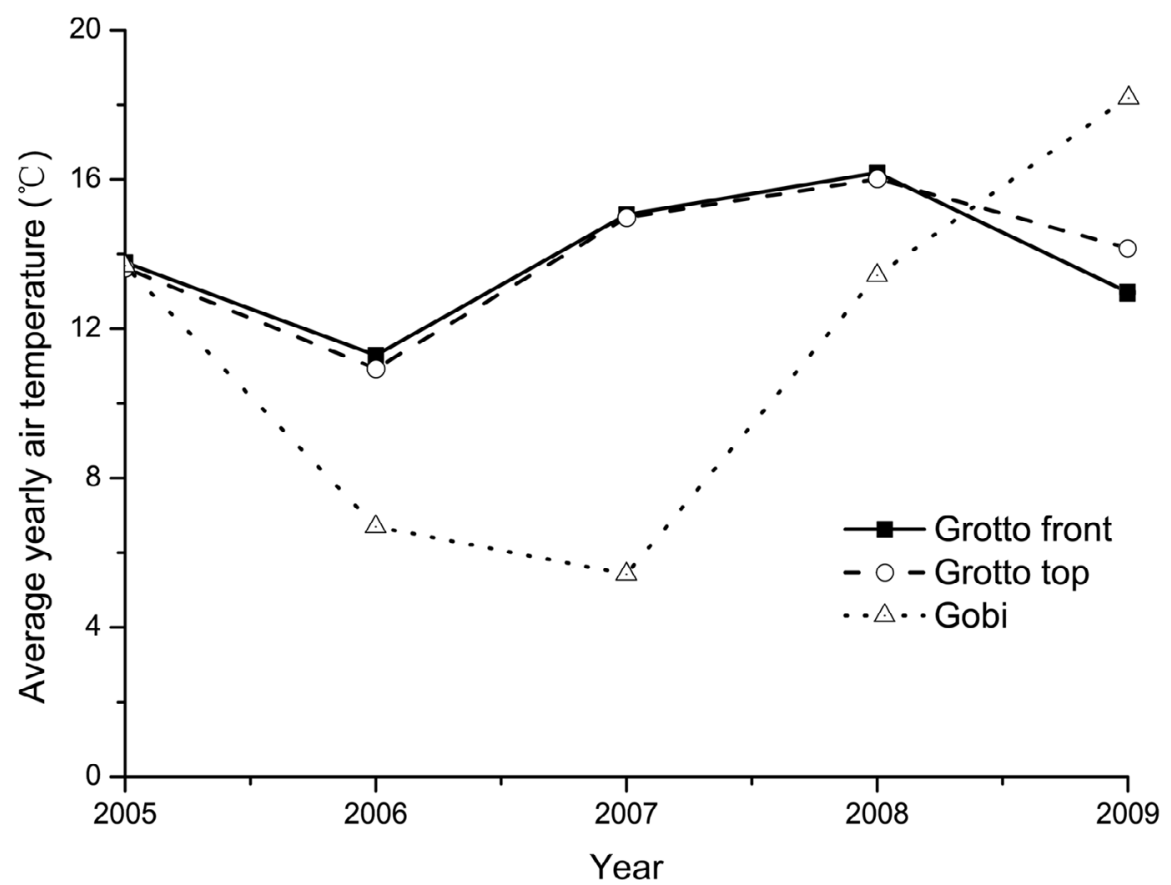

Fig. 4. Inter-annual variations of average air temperatures during 2005 - 2009.
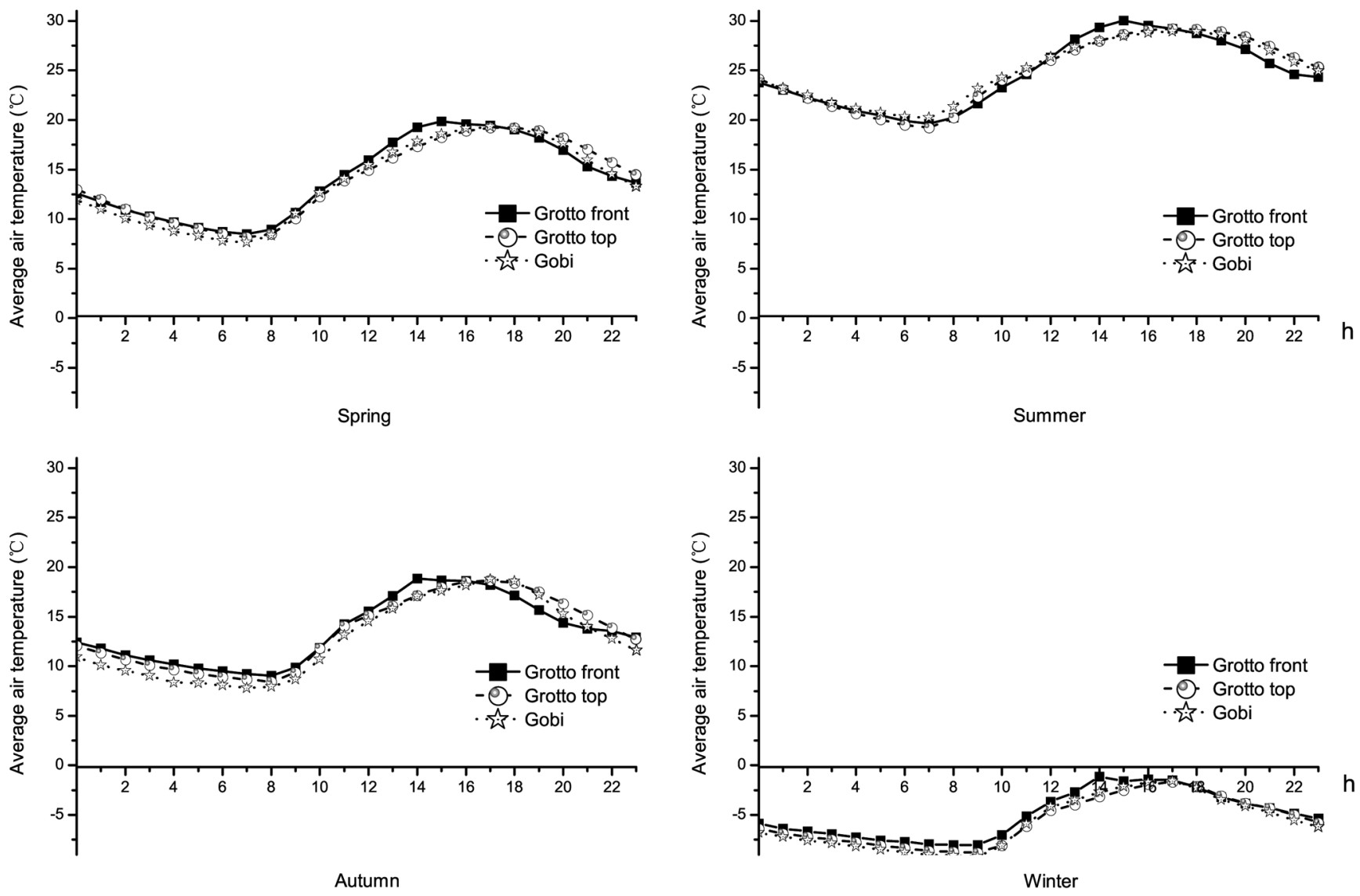

Fig. 5. Daily variation in average air temperature at IFG, OTG and IAG in different seasons during 2005 - 2009. 
Table 1. The timing of average air temperature extremes in front of the grottoes, on top of the grottoes and in the artificial Gobi during 2005 - 2009.

\begin{tabular}{lcc|cc|cc|cc}
\hline \multirow{2}{*}{ Time } & \multicolumn{2}{c|}{ Spring } & \multicolumn{2}{c|}{ Summer } & \multicolumn{2}{c|}{ Autumn } & \multicolumn{2}{c}{ Winter } \\
\cline { 2 - 10 } & Maximum & Minimum & Maximum & Minimum & Maximum & Minimum & Maximum & Minimum \\
\hline Grotto front & 15 & 6 & 15 & 7 & 14 & 8 & 14 & 9 \\
Grotto top & 18 & 7 & 17 & 7 & 17 & 8 & 17 & 9 \\
Gobi & 17 & 7 & 17 & 7 & 17 & 7 & 17 & 9 \\
\hline
\end{tabular}

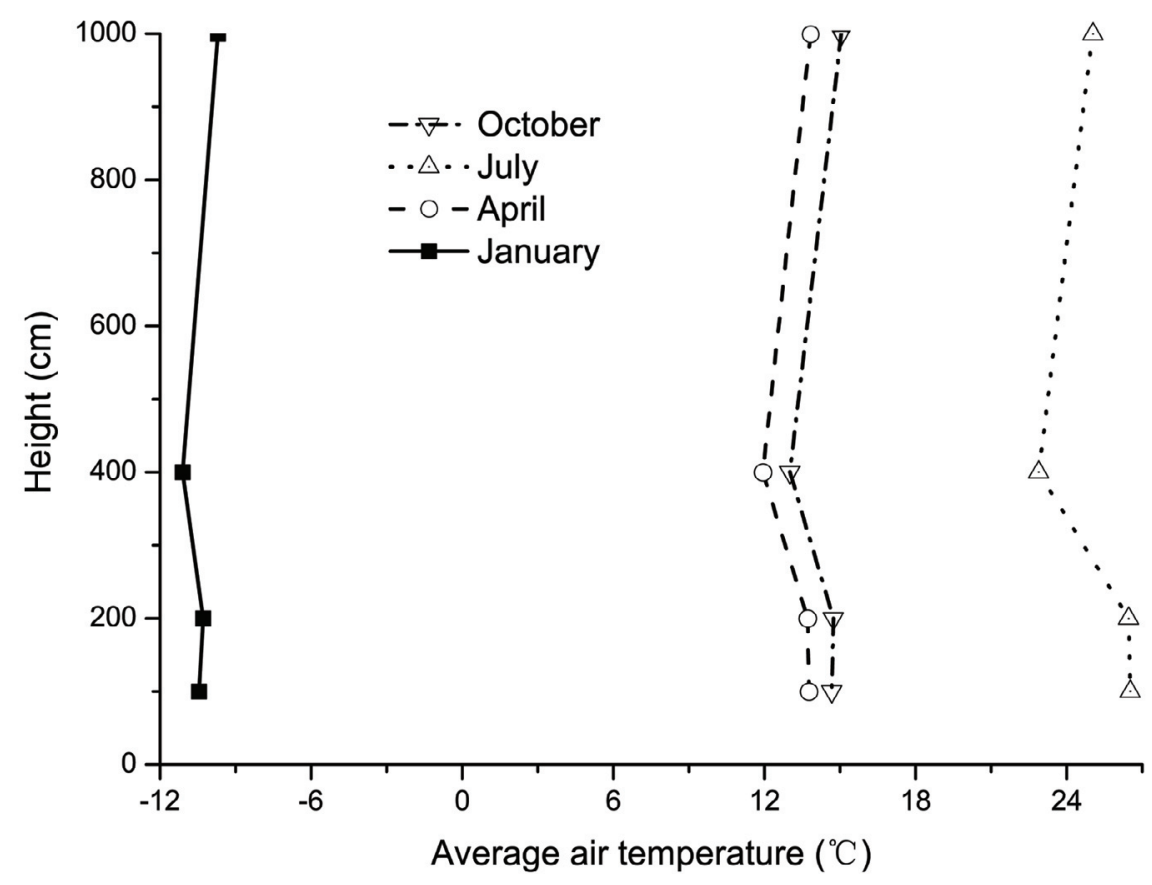

Fig. 6. The change of average air temperature with increase of height IAG during 2005 - 2009.

that the ground temperature at IFG was more stable in all seasons than that at OTG and IAG. The daily change amplitude of the ground temperature was always larger there compared to IFG and reached the minimum between 6 and $8 \mathrm{am}$. The average ground temperatures at IFG before $9 \mathrm{am}$ in spring and summer were higher than those at OTG and IAG. The reason for this is that the shelterbelts at IFG retain heat for longer periods, and the temperature response range is greater in the hummocks (OTG) and IAG. This is related to the fact that the gravel coverage in the hummocks (about $23 \%)$ is less than that at IAG $(30-40 \%)$, so the coverage could decrease the response range of the average ground temperature (negative relationship). Also, there is hysteresis in the air temperature change in the shelterbelts: after 9 am the average ground temperature suddenly increases at OTG and IAG but this occurs later in the shelterbelts due to the different specific heats of vegetation and gravel.

The gravel diameters IAG are generally $1-2,2-4$, and $4-6 \mathrm{~cm}$ (the larger-diameter gravel is in the paved area). In larger gravel the interior interstices in the gravel layer are larger than that in the original Gobi, and the surface under the gravel layer can absorb more solar radiation. Also, the coverage of the artificial Gobi $(30-40 \%)$ is greater than that in the original Gobi (about 23\%), so the artificial Gobi "cushions" the change of temperature, making the response in ground temperature slower but more extreme than that at OTG.

The weather gradually cools in autumn and winter, and solar radiation is reduced, thus lengthening the time needed to heat the underlying surface. Thus, the intersection points are delayed until 10 and $11 \mathrm{am}$, respectively. The average ground temperature at OTG and IAG were above $0^{\circ} \mathrm{C}$ between 12 am and $6 \mathrm{pm}$ in winter (Fig. 7). The gravels in the hummocks (OTG) and IAG are natural material, so the trends of average ground temperature are more consistent. However, the different gravel diameters and coverage result in differences in inflection points, amplitude, and corresponding time of the ground temperature. The average annual ground temperature showed a slight increasing trend during 2005 - 2009 (Fig. 8). 

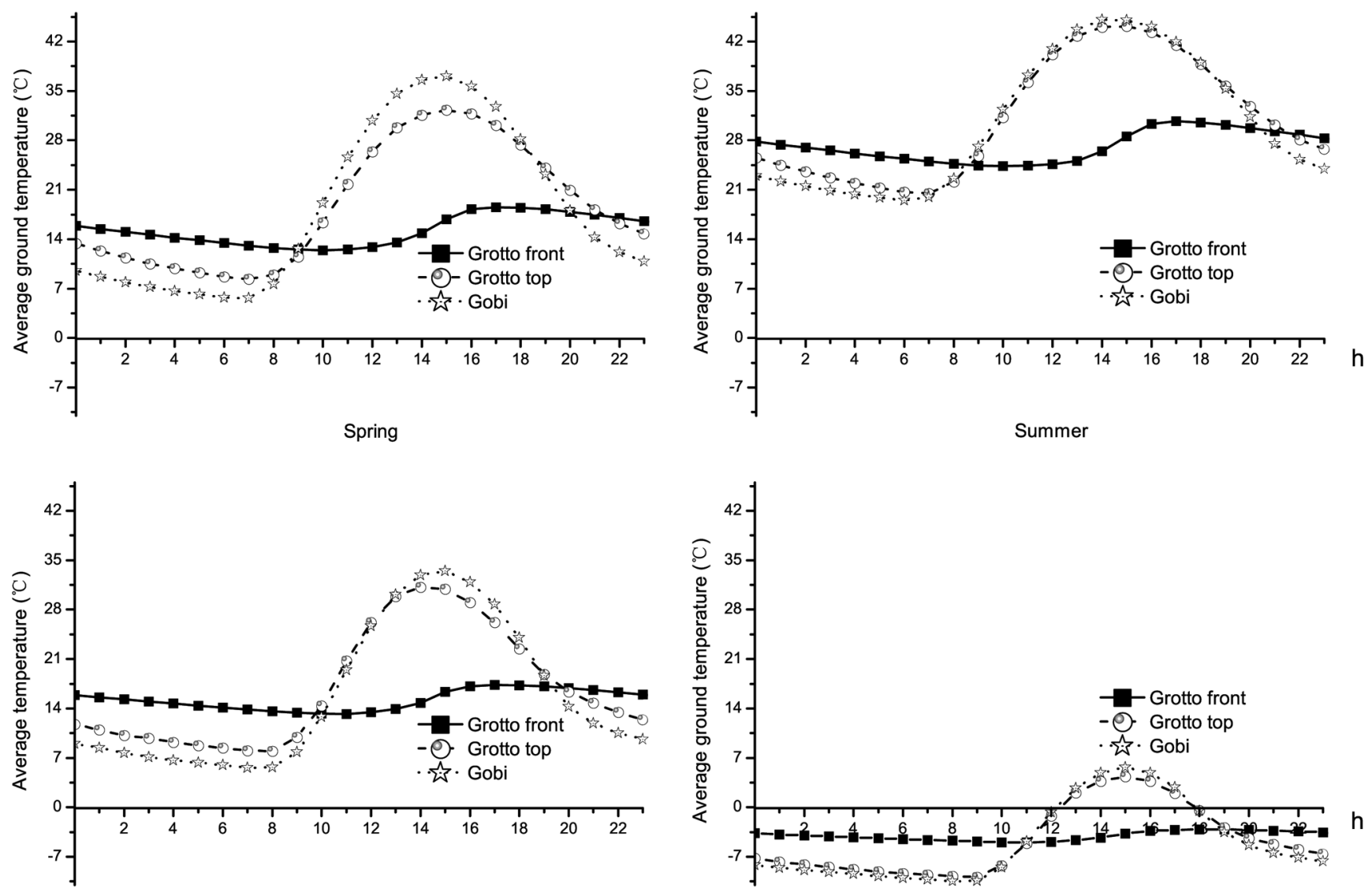

Autumn

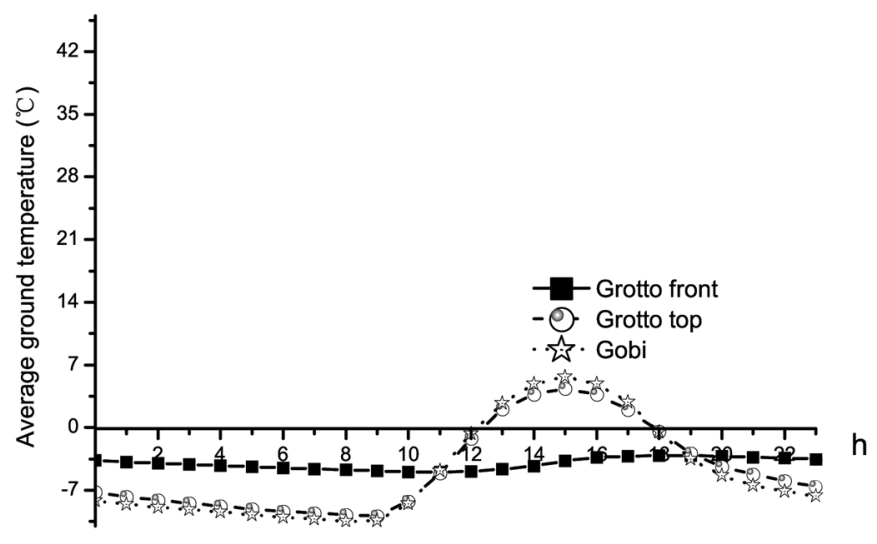

Winter

Fig. 7. Daily variation of average ground temperature at IFG and OTG, and IAG in different seasons during 2005 - 2009.

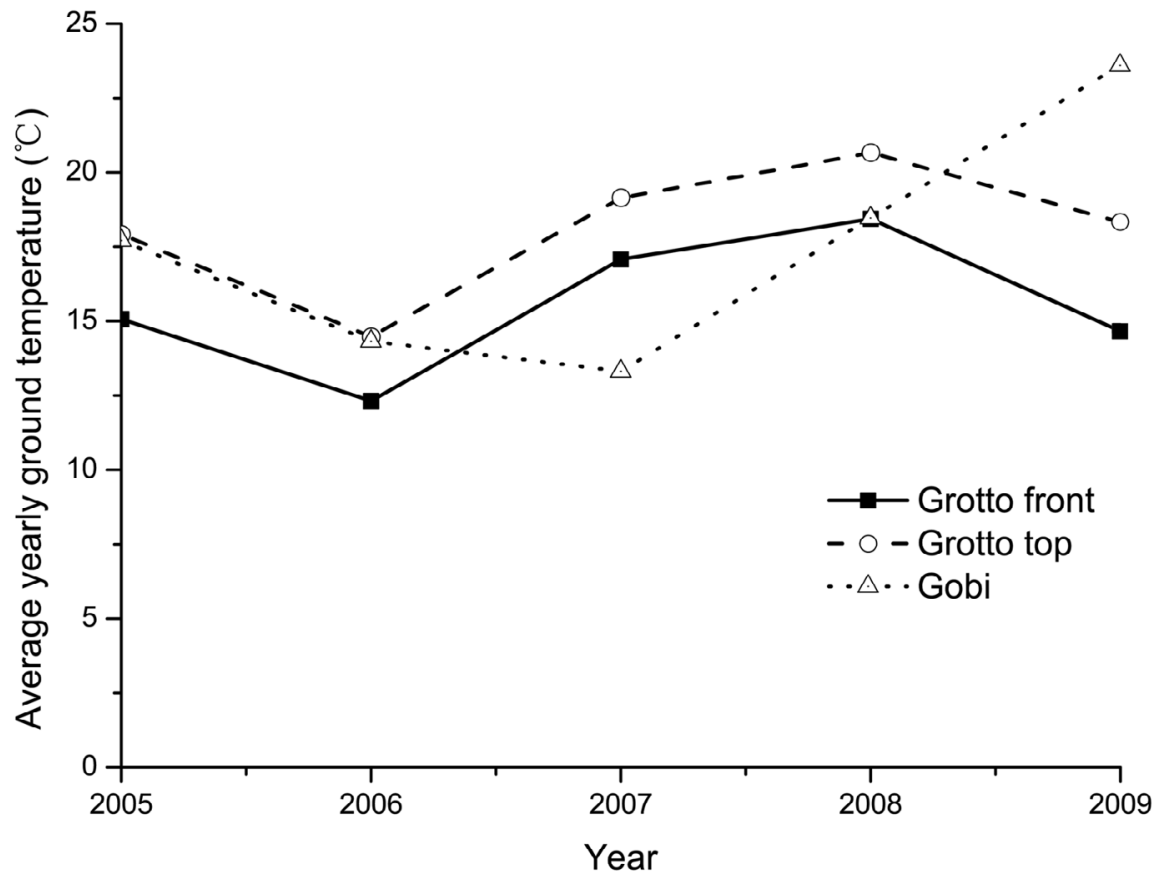

Fig. 8. Inter-annual variations of average ground temperature during 2005 - 2009. 
The data collected during the study period (Fig. 9) indicate that the general trends of absolute maximum ground temperatures were: Gobi > Grotto top > Grotto front. All of these were greater than the absolute minimum ground temperatures, which were: Grotto front $>$ Grotto top $>$ Gobi. Also, the differences between absolute maximum ground temperatures and absolute minimum ground temperatures were: Gobi > Grotto top > Grotto front. Thus, the buffer effect on the change of ground temperature in the shelterbelts at IFG is greater than that in the hummocks OTG and IAG.

\subsection{Relative Humidity}

The average monthly relative humidity at IFG (76.47\% in January) was greater than at OTG $(71.70 \%)$ and IAG $(74.36 \%)$. In June these values were $32.01 \%, 21.17 \%$, and $21.19 \%$, respectively. The relative humidity peaked in July. The curves of average monthly relative humidity were: Grotto front $>$ Grotto top $>$ Gobi (Fig. 10).

The average daily relative humidity in winter exceeded 46\% in all areas (Fig. 11); the maximums always occurred between 7 and 9 am. Maintaining the shelterbelts at IFG requires a large amount of water for irrigation. This causes an increase in moisture content and the relative humidity becomes higher, especially in winter. Besides, static wind in winter is greater than in other seasons, and the moisture in the shelterbelts may not readily be transported due to less wind. In summer, the many windy and hot days also necessitate irrigation, so small peaks in relative humidity occur in summer.

If the relative humidity is higher, the murals inside the grottoes will be exposed to more harm (moisture condensation and/or salt deliquescence). The minimum relative humidity was suitable for protecting the murals ( $\mathrm{Li}$ et al. $2012 b)$. The absolute minimum relative humidity at IFG occurred in March and May; at OTG this occurred between April and June, and at IAG this occurred in September and October (Fig. 12). Figure 13 shows that average relative humidity in January, July, October and April decreased with height. Similar to the air temperature profile at IAG, the average monthly relative humidity also first decreased then increased with measurement height.

\subsection{Wind Speed}

The average wind speed in the original landscape at OTG was higher than that at IAG and IFG, but the effect of the shelterbelt on decreasing the wind speed is obvious. The elevation differences between these sites are less than $40 \mathrm{~m}$, so not considering height effect of the wind and Ashaped nylon fence, the average yearly wind speed at IAG was $3.86 \mathrm{~m} \mathrm{~s}^{-1}$. This is about $10 \%$ lower than that at OTG

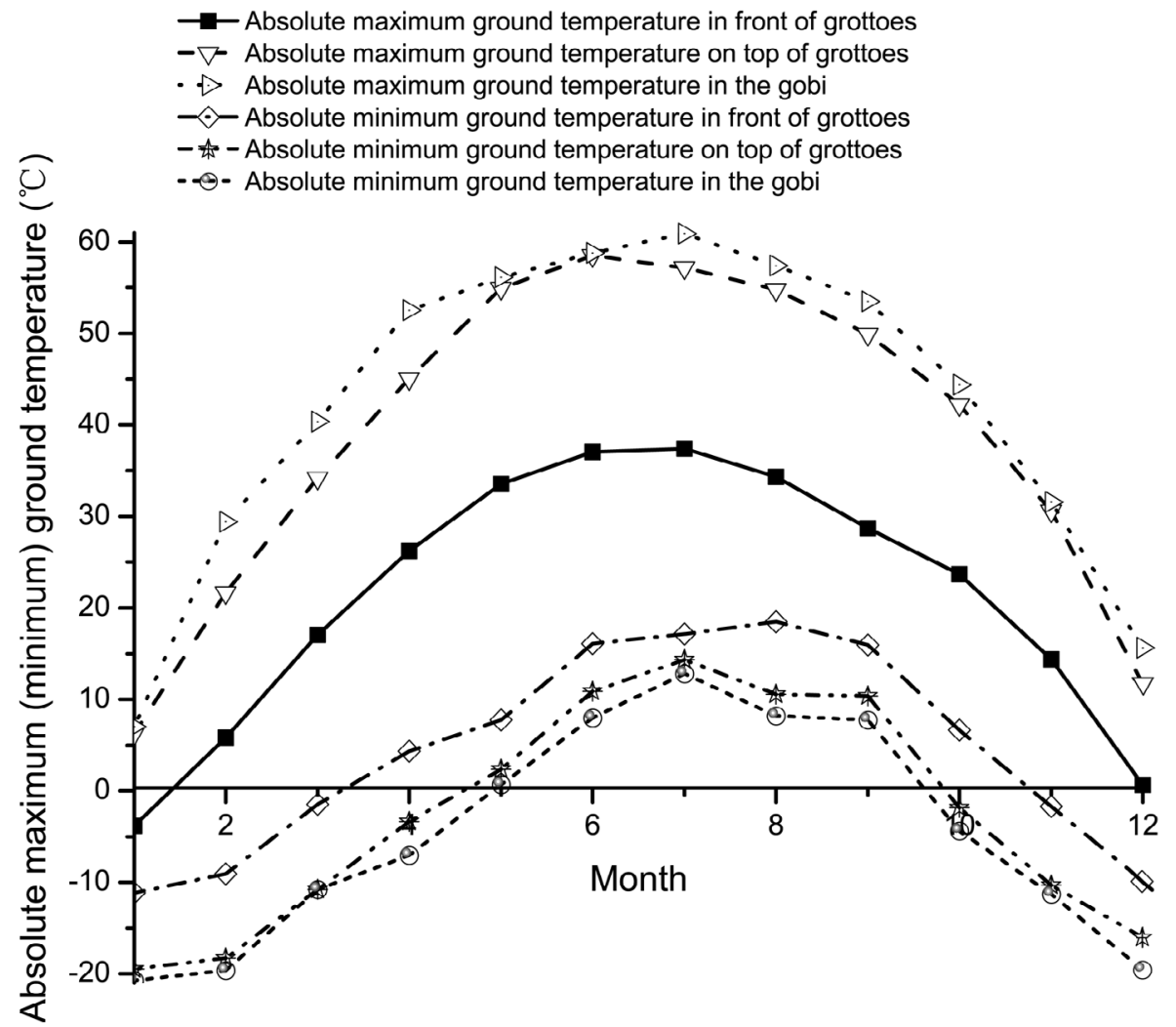

Fig. 9. Monthly variation of absolute maximum (minimum) ground temperature at IFG, OTG and IAG during 2005 - 2009. 


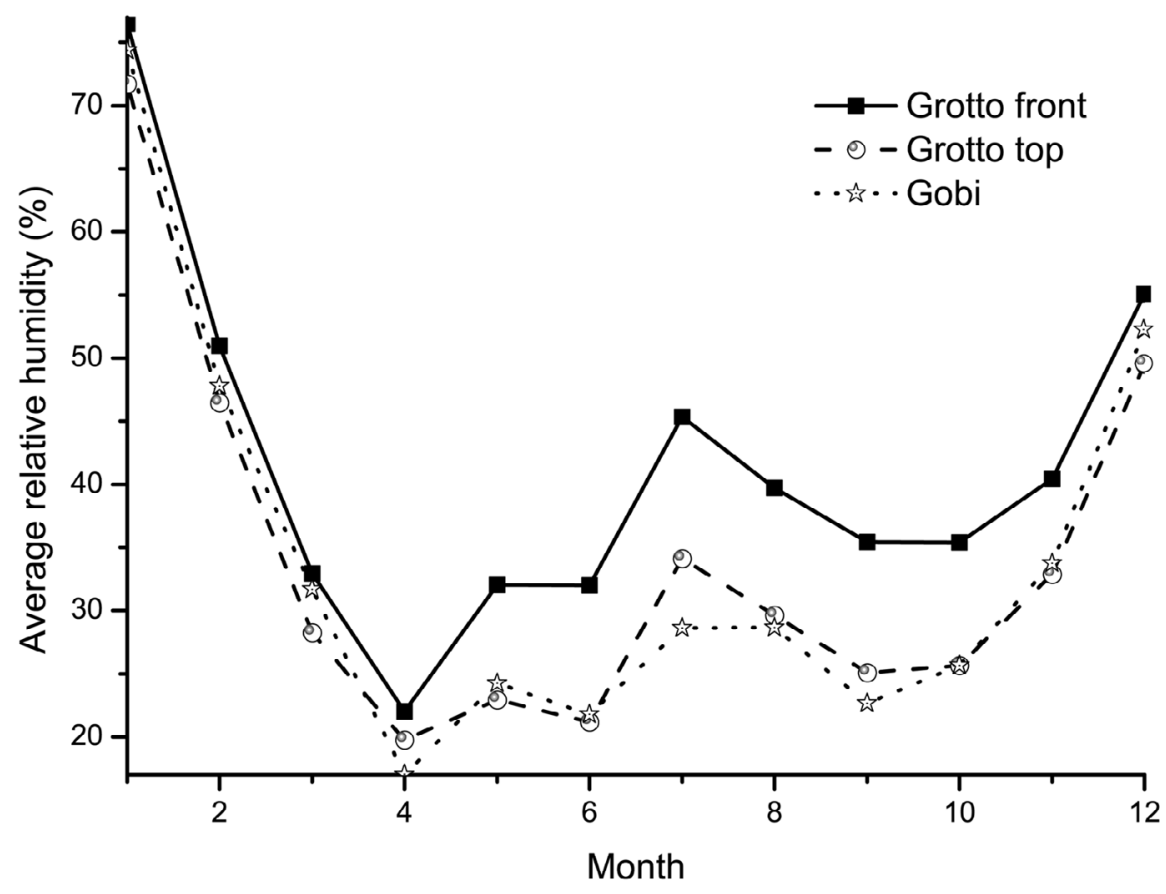

Fig. 10. Monthly variation of average relative humidityat IFG, OTG and IAG during 2005 - 2009.
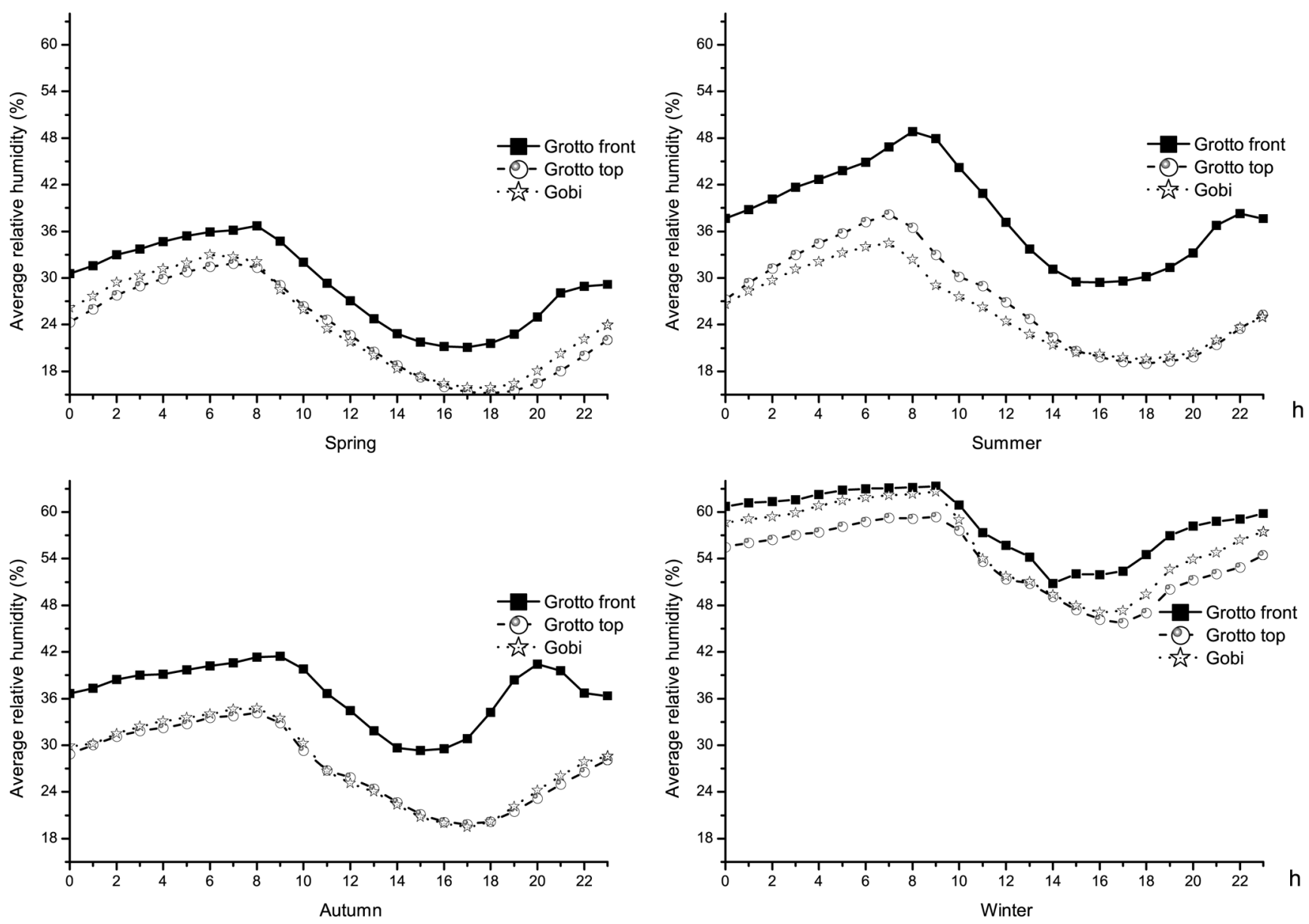

Fig. 11. Daily variation of average relative humidity at IFG, OTG and IAG during 2005 - 2009. 


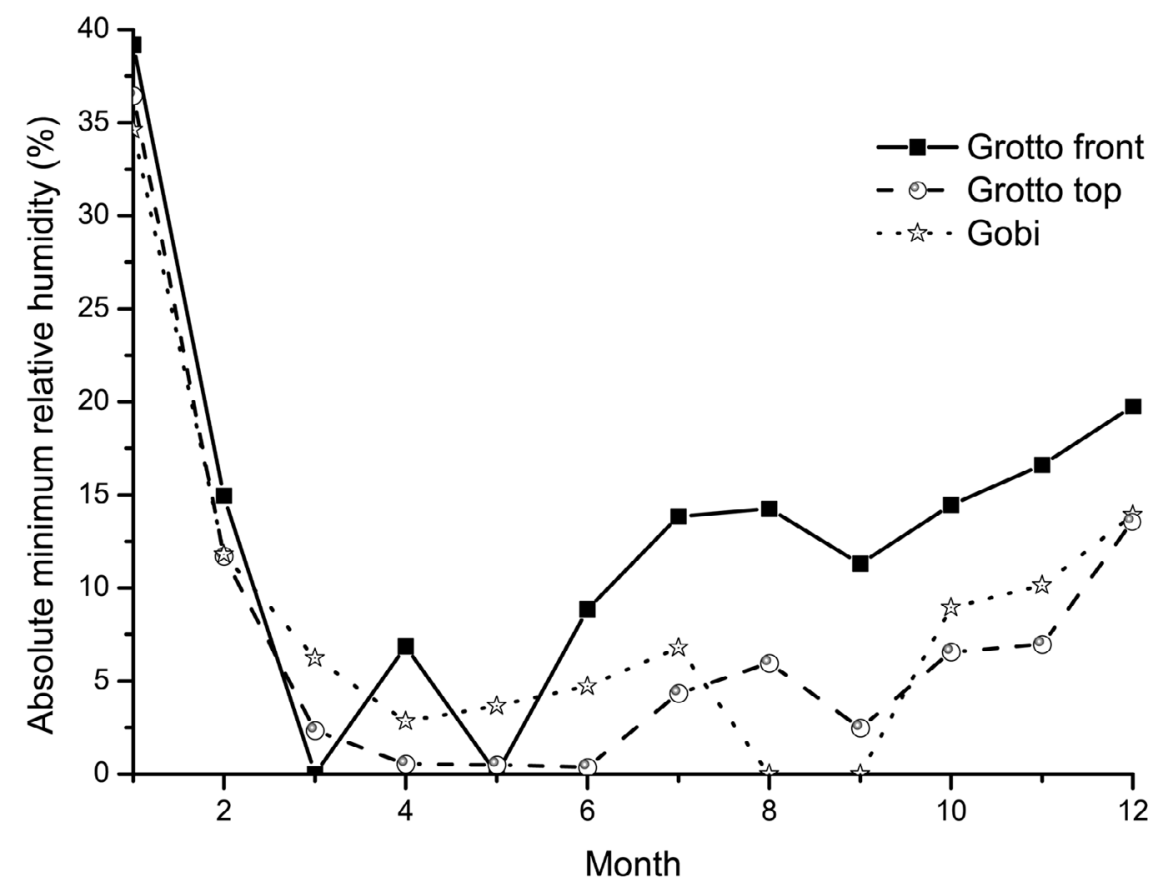

Fig. 12. Monthly variation of absolute minimum relative humidity at IFG, OTG and IAG during 2005 - 2009.

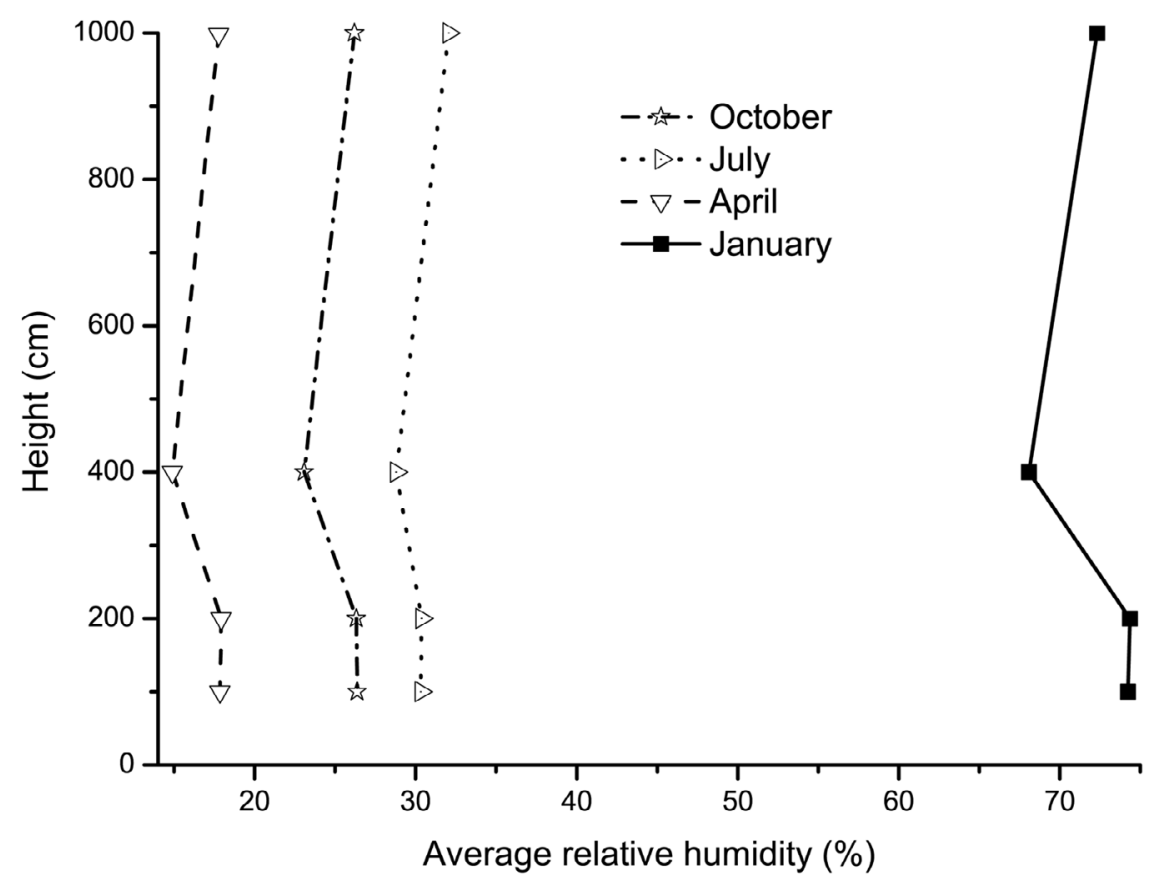

Fig. 13. The change of average relative humidity with increase of the height at IAG during $2005-2009$.

$\left(4.32 \mathrm{~m} \mathrm{~s}^{-1}\right)$, while that in the shelterbelts at IFG, the wind speed was $0.67 \mathrm{~m} \mathrm{~s}^{-1}$ (about $80 \%$ lower than that at OTG) (Table 2). This suggests that the shelterbelt's protective effect was better than that of the paving gravel at IAG. The maximum average monthly wind speed at IFG was $1.03 \mathrm{~m} \mathrm{~s}^{-1}$, and shows that the shelterbelts can effectively de- crease wind erosion to the rock walls from easterly winds.

The average wind speed at OTG was $4.60 \mathrm{~m} \mathrm{~s}^{-1}$ in May, whereas the average monthly wind speed at IAG reached its maximum in June (Fig. 14). Generally, wind speeds at OTG are often very high and are often related to the sandstorms which occur most frequently in March, April, and 
May. The absolute maximum wind speeds at OTG and IFG were 18.20 and $6.3 \mathrm{~m} \mathrm{~s}^{-1}$, respectively, in June. The absolute maximum wind speed at IAG in April (13.32 $\left.\mathrm{m} \mathrm{s}^{-1}\right)$ was close to its value in June (Fig. 15). Besides, with increase of the elevation, wind speed would decrease, so the wind speed at IFG $(1338 \mathrm{~m})$ was lower than those at OTG $(1378 \mathrm{~m})$ and IAG (1367 m). For differences related to the underlying surface it is difficult to quantity the effects of the artificial Gobi and shelterbelts.
Table 2. Average yearly wind speed $\left(\mathrm{m} \mathrm{s}^{-1}\right)$ in front of the grottoes, on top of the grottoes and in the artificial Gobi during 2005 - 2009.

\begin{tabular}{cccc}
\hline Year & Grotto front & Grotto top & Gobi \\
\hline 2005 & 0.61 & 4.21 & 3.99 \\
2006 & 0.62 & 4.19 & 4.04 \\
2007 & 0.67 & 4.57 & 4.28 \\
2008 & 0.66 & 4.49 & 3.75 \\
2009 & 0.77 & 4.15 & 3.26 \\
\hline
\end{tabular}

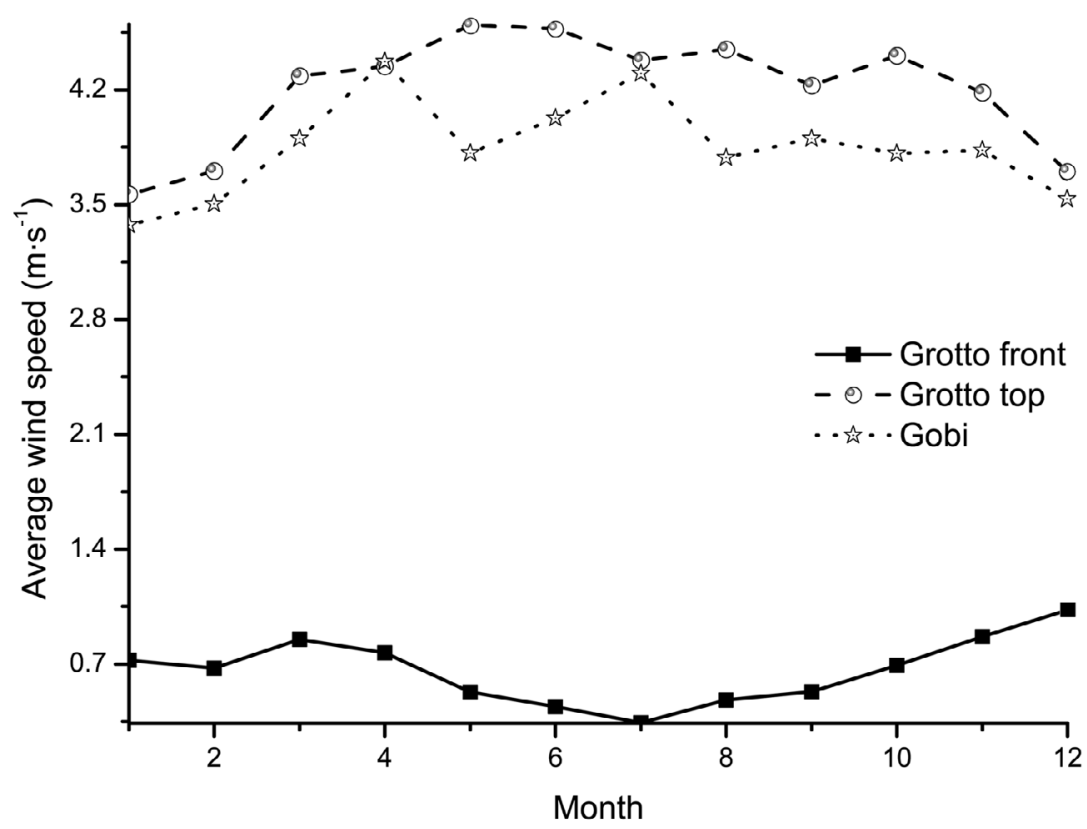

Fig. 14. Monthly variation of average wind speed at IFG, OTG and IAG during 2005 - 2009.

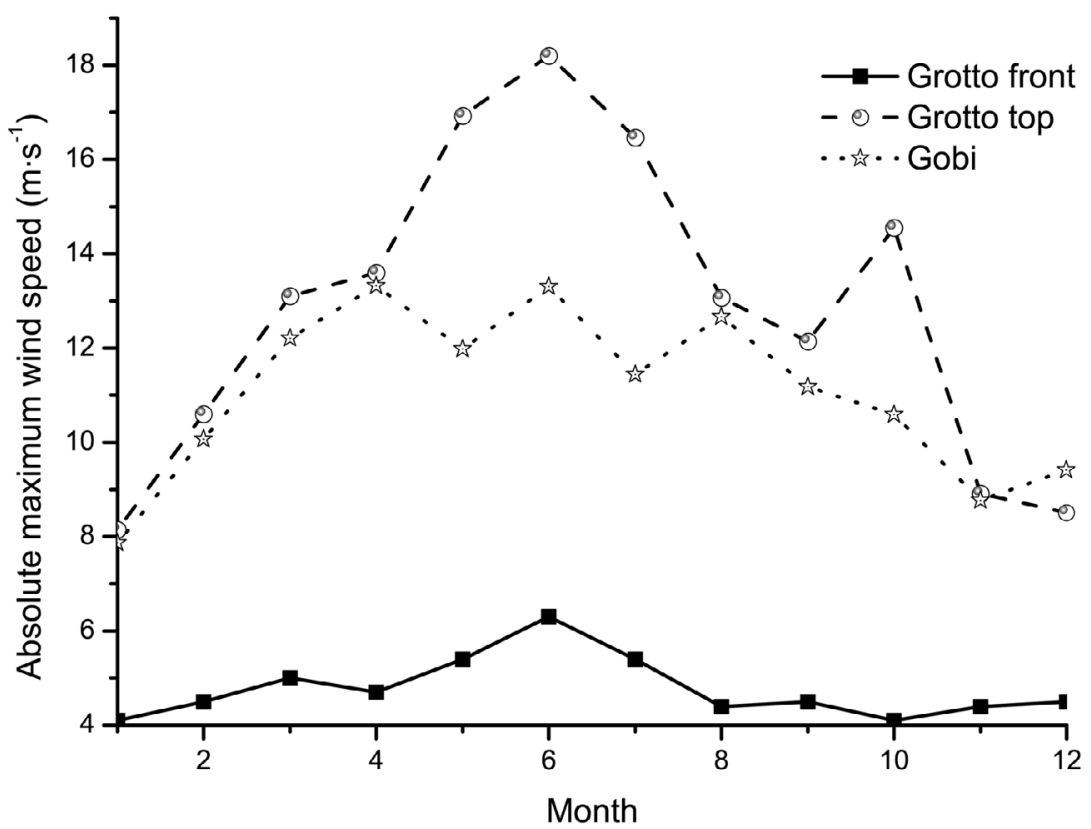

Fig. 15. Monthly variation of absolute maximum wind speed at IFG, OTG and IAG during 2005 - 2009. 
The artificial Gobi increases the surface roughness and coverage, decreases the interstices between gravels, enlarges the contact area between air currents and the gravel layer, enhances loss of the energy of air currents, reduces wind speeds above that gravel layer, and thus increases the initial wind speed of sand-blowing wind (the minimum wind speed when sand particles are transported by wind; (Li 2012). The average wind velocities at IAG first increase and then decrease with the increase of measurement height, which is opposite to the temperature and relative humidity profiles. The average wind speeds at heights of 2, 4, and 10 $\mathrm{m}$ above the artificial Gobi are presented in Fig. 16. When the wind blew over the dunes of Mount Mingsha on top of the Mogao Grottoes to the downside, the air flow would be faster next to the surface of the Gobi, so the wind speeds at the Gobi decreased from 4 to $10 \mathrm{~m}$ for all months.

\subsection{Solar Radiation}

Comparison of short wave radiation at stations IFG and IAG showed average solar radiation reached the maximum values in June of 121.42 and $73.25 \mathrm{~W} \mathrm{~m}^{-2}$ respectively. The minimum of average solar radiation at IFG was $31.31 \mathrm{~W} \mathrm{~m}^{-2}$ in January, while at IAG, the minimum was $36.77 \mathrm{~W} \mathrm{~m}^{-2}$ (Fig. 17). The average daily solar radiation at IFG always reached the maximum at $2 \mathrm{pm}$, and the maximum was $644.98 \mathrm{~W} \mathrm{~m}^{-2}$ in summer, and the minimum was $315.11 \mathrm{~W} \mathrm{~m}^{-2}$, showing a sharp peak. The average daily solar radiation at IAG decreased in the order of in summer, spring, autumn and winter. The maximum was $185.86 \mathrm{~W} \mathrm{~m}^{-2}$ and the minimum was $153.54 \mathrm{~W} \mathrm{~m}^{-2}$. The single peak of average solar radiation at IFG was related to the material strengthened and rounded off on the body of the cliffs at the grottoes. At the same time, the cliff body can act like a large mirror which reflects the sun's short wave radiation, and the shelterbelts also reflect short wave radiation (Fig. 18). In the artificial Gobi, the atmospheric inversion radiation, solar radiation and reflective radiation reached their maximum in June at the same time, while long wave radiation and net radiation at the underlying surface had the minimum. The minimum for reflective radiation was $-5.2 \mathrm{~W} \mathrm{~m}^{-2}$ in January, while net radiation was the negative between February and October because the radiation received by the gravel layer was less than radiation emitted, losing heat. But positive values occurred between November and January, when the gravel layer retained heat. On the whole, the artificial Gobi results in a cooling action in the air (Fig. 19).

\subsection{Atmospheric Pressure}

The atmospheric pressure at IFG and IAG showed similar trends. At IFG, the atmospheric pressure reached the maximum of $868.84 \mathrm{hPa}$ in November, but at IAG the maximum $(870.85 \mathrm{hPa})$ was in December. In both locations the atmospheric pressures were highest in winter and lowest in summer, but between March and June it was slightly higher at IFG than IAG. During the summer, a symmetrical pattern was formed for the atmospheric pressure at IFG and IAG. At all times the atmospheric pressure at IAG was higher than that at IFG. Because the elevation difference between WS-F

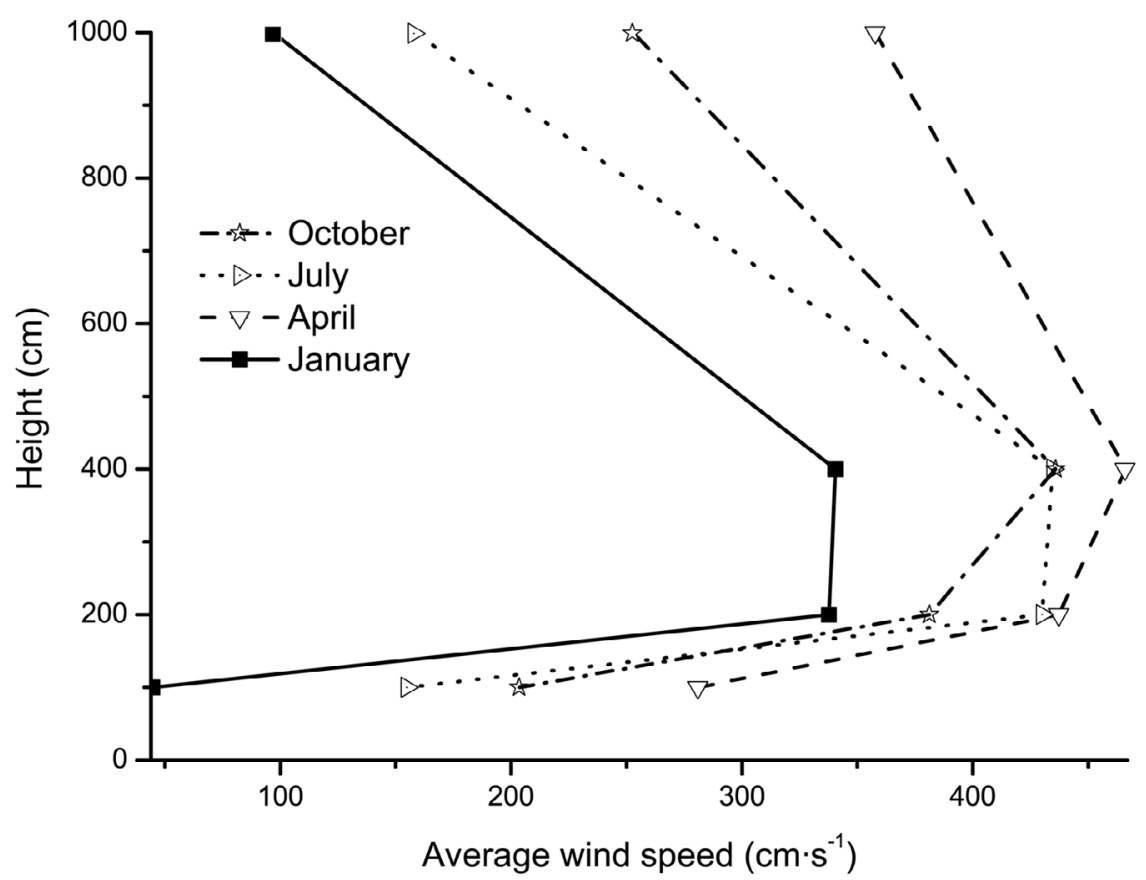

Fig. 16. The change variation of average wind speed with increase of height at IAG during $2005-2009$. 


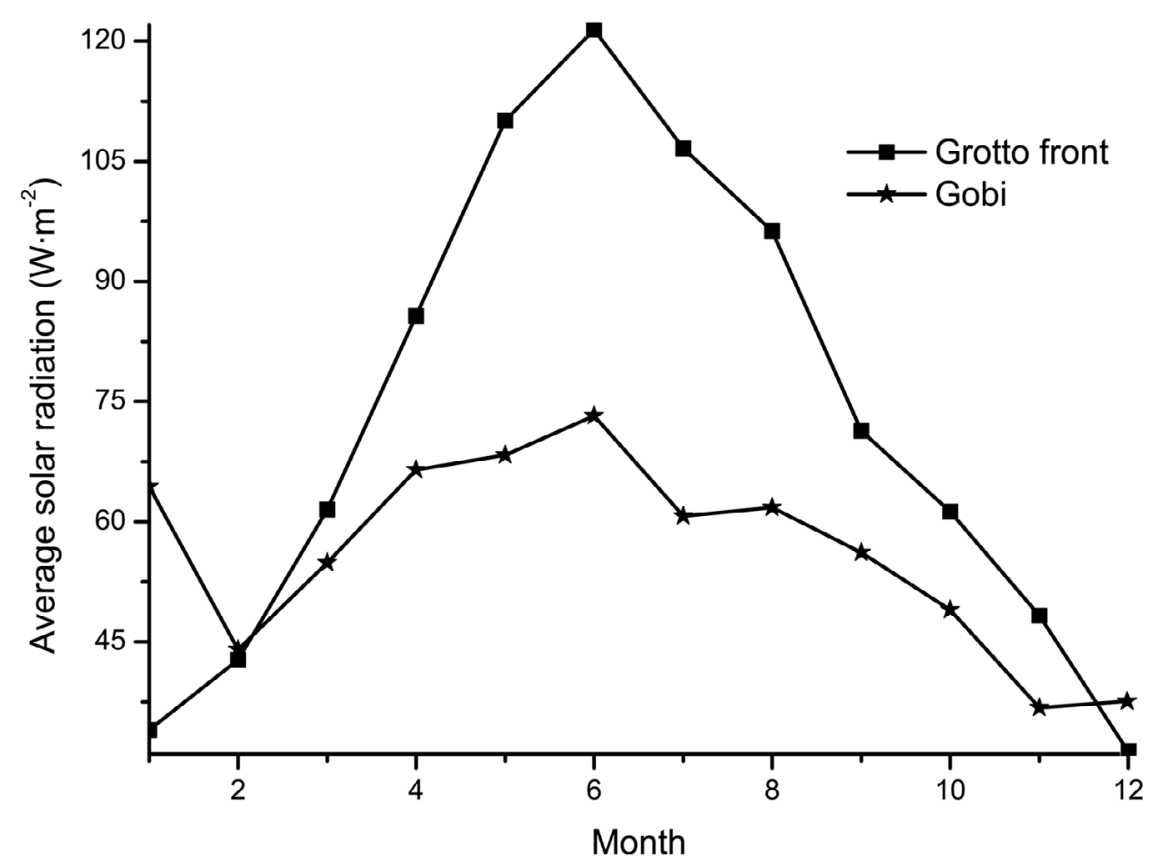

Fig. 17. Monthly variation of average solar radiation at IFG and IAG during 2005 - 2009.
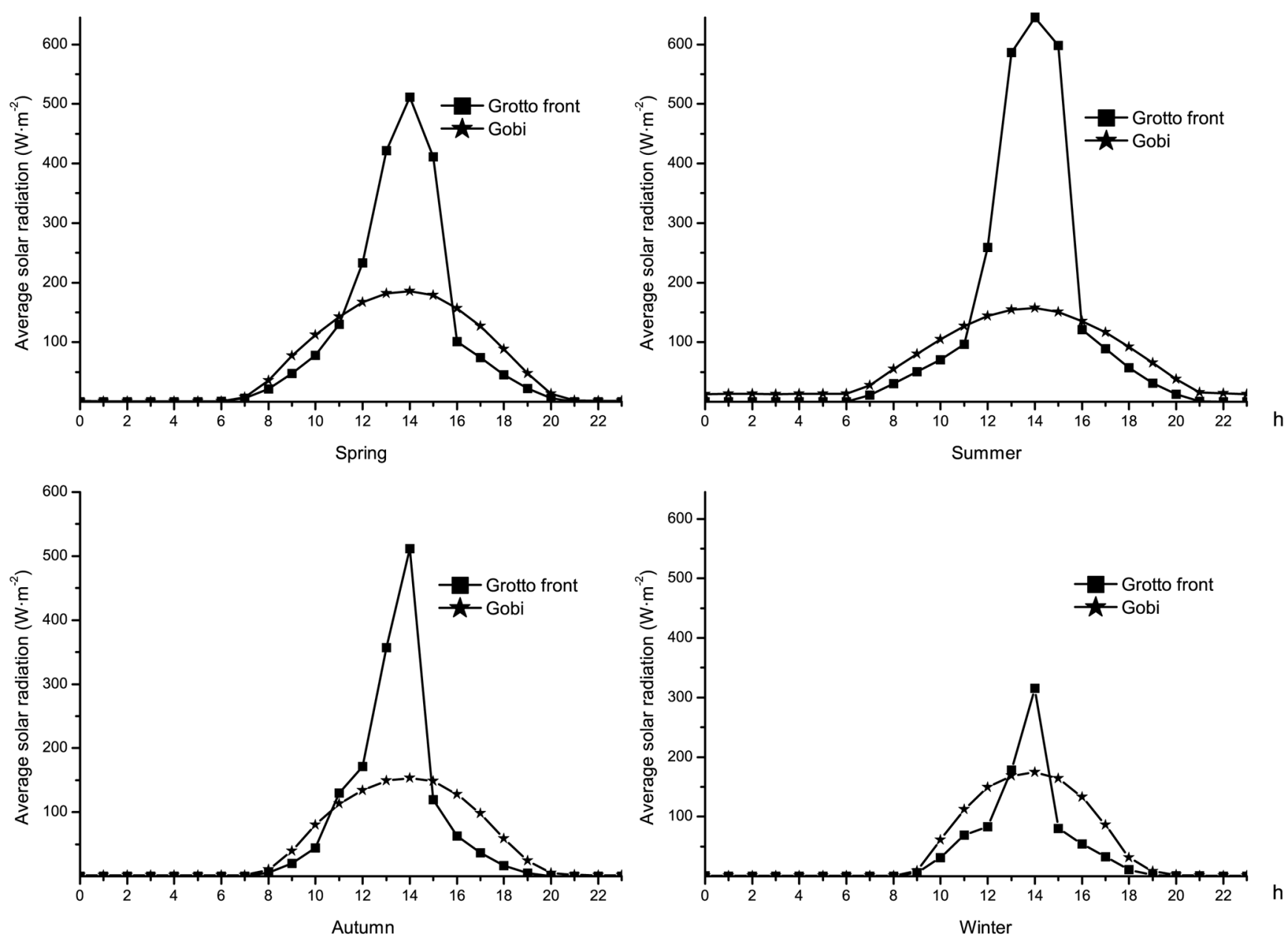

Fig. 18. Daily variation of average solar radiation at IFG and IAG in different seasons during 2005 - 2009. 
$\longrightarrow$-Atmospheric inversion radiation

$-\nabla$ - Solar radiation

.. Underlying surface long wave radiation

- it - Reflective radiation

-.๑-. Net radiation

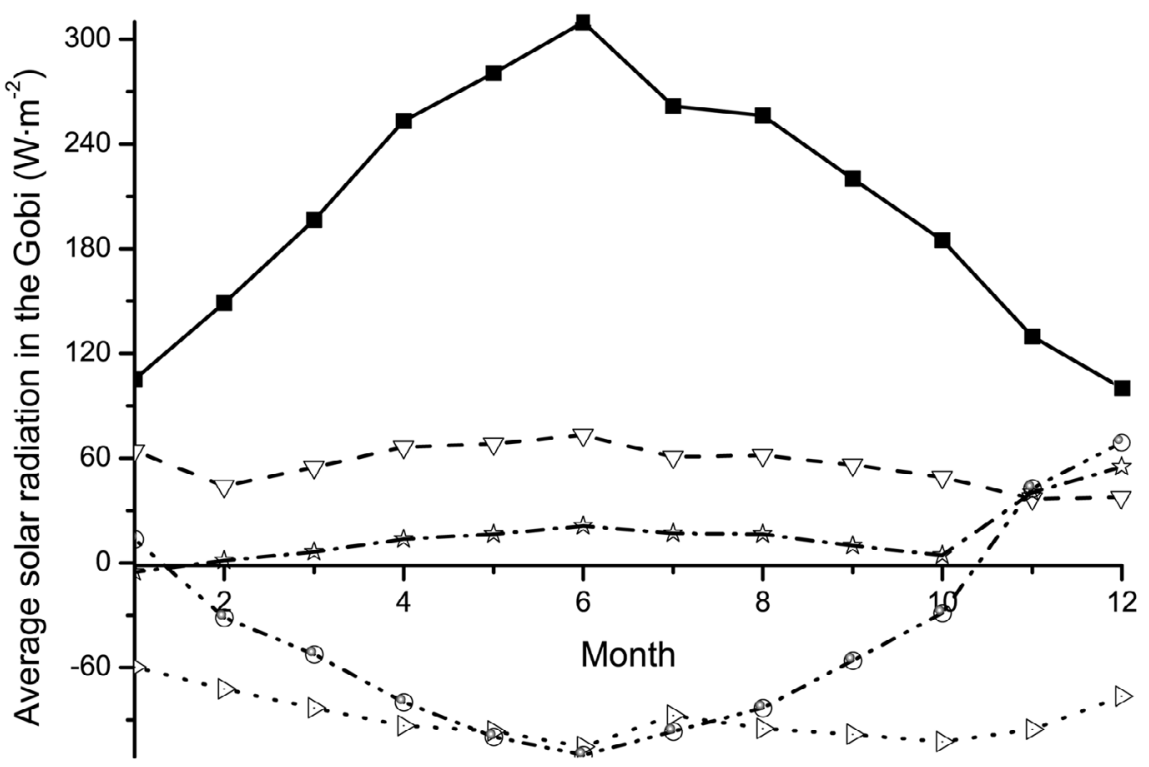

Fig. 19. Monthly variation of atmospheric radiation at IAG during 2005 - 2009.

and WS-G is only $29 \mathrm{~m}$, the pressure difference could be neglected. The minimum at IFG $(1338 \mathrm{~m})$ was $857.91 \mathrm{hPa}$ in June, and at IAG (1367 m) the minimum was $858.24 \mathrm{hPa}$ in July. The artificial Gobi shows higher atmospheric pressure because interior interstices in the gravel layer can retain air flow for a time. Because of the small difference in elevation between WS-F and WS-G, the atmospheric pressure changed similarly through time. However, because of the different underlying surfaces, the extremes of average atmospheric pressure in the shelterbelts and in the Gobi showed an obvious difference of 1 month (Table 3). The shelterbelts create shadows and lessen air circulation, and the humid air is more difficult to diffuse, so the extremes of average monthly atmospheric pressure at IFG occurred ahead of those at IAG (Fig. 20).

\section{DISCUSSION}

There are several drawbacks in the methodology used in this study. Our micrometeorological observations at the Mogao Grottoes are based on limited measurements from local meteorological stations, and these were not precise enough to explain all of the trends. In addition, the measurement protocols and interpretation of data differed according to the persons doing the analysis. It was regrettable that typical meteorological variables in the shelterbelts at IFG and in the hummocks at OTG were not amenable to gradi- ent observation. Also, the number of monitoring points for gradient observations at IAG should have been increased. The soil temperature should be monitored at IFG, OTG, and IAG. Wind speed will decrease with increase of the elevation, but the difference in underlying surfaces at the weather stations makes it difficult to quantify the effect. Experiments are needed to clearly understand the patterns in wind speed. Finally, the sharp peak in average daily solar radiation at IFG cannot be properly explained by the methodology used here. It seems necessary to install radiation instruments to monitor radiation at different parts of the cliffs and trees at different times to provide a more credible explanation for the observations collected here.

\section{CONCLUSIONS}

The Mogao Grottoes are located in a harsh aeolian environment. Because of different local underlying surfaces, the protective shelterbelts and the artificial Gobi result in micrometeorological differences. These differences can prevent or mitigate the severity of sandstorms and decrease the intensity of wind abrasion and destruction of the grottoes. Although the shelterbelts at IFG are effective in reducing wind speed, the slow infiltration of irrigation water in the shelterbelts can pose a threat to the murals in the grottoes. For these reasons, the artificial Gobi is the best protective choice. The conclusions from this study are: 
Table 3. The extremes of average atmospheric pressure and corresponding months in the shelterbelts and in the Gobi during 2005 - 2009.

\begin{tabular}{cccc|cccc}
\hline & \multicolumn{3}{c|}{ Minimum } & \multicolumn{4}{c}{ Maximum } \\
\hline Grotto front & 857.808 & Gobi & 858.236 & Grotto front & 868.837 & Gobi & 870.854 \\
Month & 8 & Month & 7 & Month & 11 & Month & 12 \\
\hline
\end{tabular}

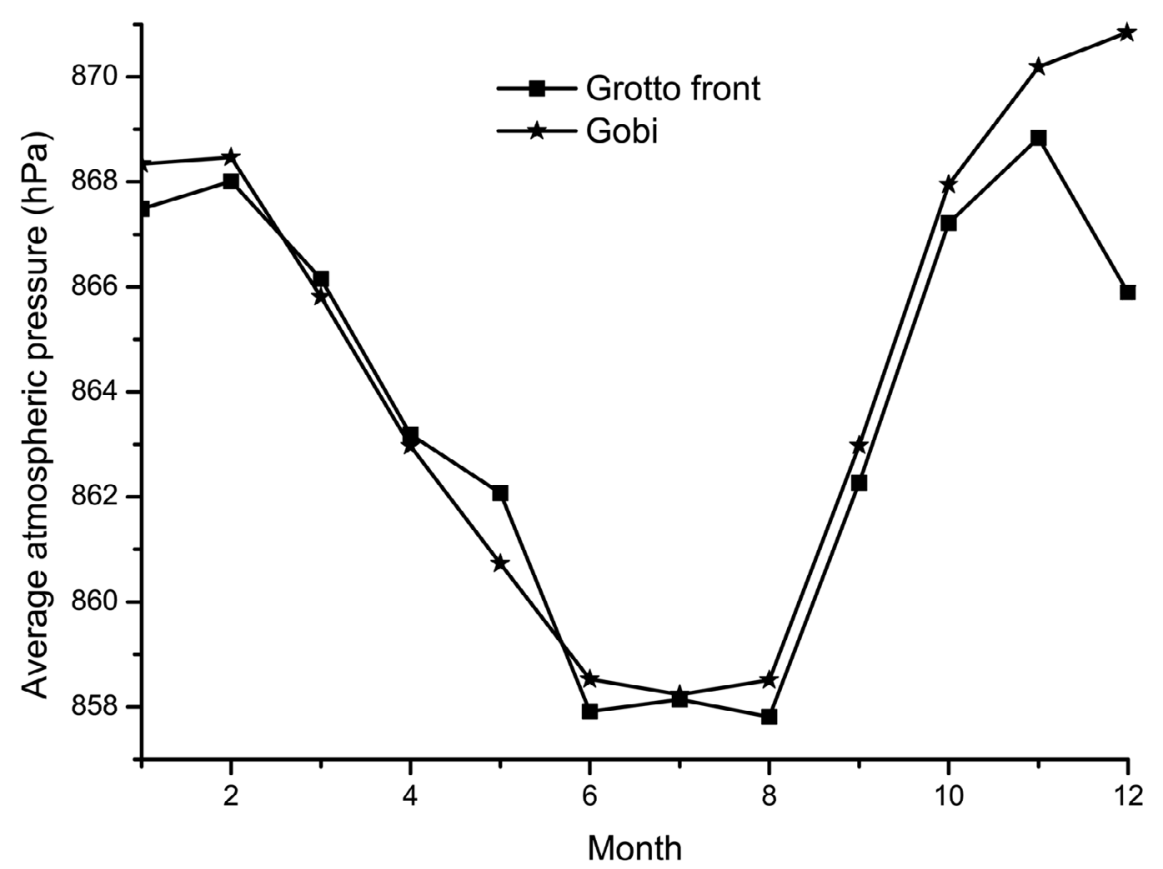

Fig. 20. Monthly variation of average atmospheric pressure at IFG and IAG during 2005 - 2009.

(1) The average monthly temperatures at IFG, OTG, and IAG were only slightly different, showing diurnal temperature cycles. The artificial Gobi was more susceptible to extremes in temperature and can thus be considered an indicator of surges in temperature amplitude. The temperature profile in the Gobi showed that average monthly temperature tended to first decrease and then increase with the increase of height, regardless of season and month. The minimum of average daily temperature at IFG, OTG, and IAG occurred between 7 and 9 am in summer and winter.

(2) The shelterbelts at IFG have a heat-retaining effect. The artificial Gobi has a faster response and wider response range to ground temperature than the coarse gravels of the original topography on top of the grottoes.

(3) Irrigation water in the shelterbelts caused the average monthly relative humidity at IFG to be higher than at OTG and in the Gobi; in all three locations the average daily relative humidity was higher in winter than in other seasons. However, the higher relative humidity IFG is detrimental to the murals. The average monthly rela- tive humidity at IAG tended to first decrease and then increase with the increase of height, similar to average monthly temperature IAG.

(4) The wind speed at IAG tends to first increase and then decrease with the increase of height.

(5) The profile of average daily solar radiation at IFG forms a sharp peak and at IAG forms a parabola, but these vary in different seasons. The gravel layer at IAG loses heat between February and October and absorbs heat between November and January.

(6) Because the front of the grottoes and the Gobi are relatively close together, the monthly variation of atmospheric pressure in those locations was similar. Atmospheric pressure at IAG and at IFG formed symmetrical structure with similar up and down type between June and August. The extremes of average atmospheric pressure at IFG occurred 1 month earlier than at IAG.

Acknowledgement This research was supported jointly by National Science and Technology Support Program (2012BAC08B07), Natural Science Foundation of China 
(No. 41001005) and Civil Test Application Data Processing (Y1141401SN).

\section{REFERENCES}

Bounoua, L., R. DeFries, G. J. Collatz, P. Sellers, and H. Khan, 2002: Effects of land cover conversion on surface climate. Clim. Change, 52, 29-64, doi: 10.1023/a: 1013051420309. [Link]

Charney, J. G., 1975: Dynamics of deserts and drought in the Sahel. Q. J. R. Meteorol. Soc., 101, 193-202, doi: 10.1002/qj.49710142802. [Link]

Chou, S. H., R. J. Curran, and G. Ohring, 1981: The effects of surface evaporation parameterizations on climate sensitivity to solar constant variations. J. Atmos. Sci., 38, 931-938, doi: 10.1175/1520-0469(1981)038<0931: TEOSEP > 2.0.CO;2. [Link]

Golitsyn, G. S., V. P. Kukharets, and H. G. Nalbandyan, 2004: Heat exchange between the atmosphere and the non-uniform underlying surface under nonstationary radiative heating: A model and measurements. Theor. Appl.Climatol., 78, 195-201, doi: 10.1007/s00704-0040055-6. [Link]

Gorchakov, G. I., B. M. Koprov and K. A. Shukurov, 2004: Wind effect on aerosol transport from the underlying surface. Izv. Atmos. Ocean. Phys., 40, 679-694.

Hara, Y., I. Uno, and Z. Wang, 2006: Long-term variation of asian dust and related climate factors. Atmos. Environ., 40, 6730-6740, doi: 10.1016/j.atmosenv.2006.05.080. [Link]

Ishizuka, M., M. Mikami, Y. Yamada, F.Zeng, and W. Gao, 2005: An observational study of soil moisture effects on wind erosion at a gobi site in the Taklimakan Desert. J. Geophys. Res., 110, D18S03, doi: 10.1029/2004 JD004709. [Link]

Jin, Y.Q.,F. Chen, and M. Chang, 2004: Retrievals of underlying surface roughness and moisture from polarimetric pulse echoes in the specular direction through stratified vegetation canopy. IEEE Trans. Geosci. Remote Sensing, 42, 426-433, doi: 10.1109/TGRS.2003.8188 10. [Link]

Kaczenskya,P., N.Enkhsaikhan, O.Ganbaatar, and C. Walzer, 2008: The Great Gobi B Strictly Protected Area in Mongolia - Refuge or sink for wolves canis lupus in the gobi. Wildlife Biol., 14, 444-456, doi: 10.2981/0909-63 96-14.4.444. [Link]

Kukharets, V. P., H. G. Nalbandyan, and T. Foken, 2000: Thermal interactions between the underlying surface and a nonstationary radiation flux. Izv. Atmos. Ocean. Phys., 36, 318-325.

Lee, Y. C., X. Yang, and M. Wenig, 2010: Transport of dusts from East Asian and non-East Asian sources to Hong Kong during dust storm related events 19962007. Atmos. Environ., 44, 3728-3738, doi: 10.1016/j. atmosenv.2010.03.034. [Link]

Li, G. S., 2012: The monitoring research of environmental benefits about several methods of aeolian sand comprehensive system in Mogao Grottoes, Dunhuang. In: Cold and Arid Regions Environmental Engineering Research Institute, Chinese Academy of Sciences. University of Chinese Academy of Sciences, Lanzhou.

Li, G. S., J. J. Qu, W. F. Wang, and W. Yang, 2012a: Overall efficiency of a v-shaped nylon net fence in preventing sand damage to the Mogao Grottoes. Sci.Cold Arid Reg., 4, 163-174.

Li, G. S., W. F. Wang, J. J. Qu, and M. H. Song, 2012b: Study on temperature and humidity environment of grotto 72 at the Mogao Grottoes in Dunhuang, China. Int. J. Climatol., doi: 10.1002/joc.3553. [Link]

Liang, Y., X. C. Liu, G. X. Zhang;, H. J. Li, and W. Huo, 2005: Study on climatic transition in a desert hinterland-Gobi desert-oasis zone in the Tarim Basin, Xinjiang. Arid Zone Res., 22, 332-335.

Lykosov, V. N. and L. N. Gutman, 1972: Turbulent boundary-layer over a sloping underlying surface. Izv. Atmos. Ocean. Phys., 8, 799.

Marshunova, M. S., 1961: Principle regularities of the radiation balance of the underlying surface and of the atmosphere in the Arctic. Tr. Arkt. Antarkt. NauchnoIssled. Inst. 229: 51-103. (in Russian)

Pankova, E. I., 2008: Environmental conditions and soils of natural oases in the Alashan Gobi Desert, Mongolia. Eurasian Soil Sci., 41, 827-836, doi: 10.1134/S10642 29308080048. [Link]

Parungo, F. P., 1996: Aeolian Transport of Gobi Dust and Its Radiation Effects. Pergamon, London, 916-920 pp.

Qu, J., N. Huang, G. Dong, and W. Zhang, 2001: The role and significance of the Gobi Desert pavement in controlling sand movement on the cliff top near the Dunhuang Magao Grottoes. J. Arid. Environ., 48, 357-371, doi: 10.1006/jare.2000.0748. [Link]

Wang, H., Z. Y. Hu, D. L. Li, Y. Z. Zhao, and W. Q. Ma, 2009: Comparative of climatologic characteristics of the surface radiation balance on Dingxin Gobi and Zhangye oasis and desert underlaying surfaces in Heihe watershed, Gansu. J. Glaciol. Geocryol., 31, 464-473.

Wang, J., W. G. M. Bastiaanssen, Y. Ma, and H. Pelgrum, 1998: Aggregation of land surface parameters in the oasis-desert systems of north-west China. Hydrol. Process., 12, 2133-2147, doi: 10.1002/(SICI)1099-1085(19 981030)12:13/14<2133::AID-HYP725>3.3.CO;2-Y. [Link]

Wu, J. K., J. Wang, Y. J. Ding, B. S. Ye, and X. Gao, 2010: Contrastive study on radiation budget in cropland, grassland and desert in arid area of northwest China. Plateau Meteorol., 29, 645-654.

Yu, J. Y., Y. W. Wang, and C. W. Chang, 2010: Asian dust 
storm activity and its association with atmospheric circulation from 1995 to 2006. Terr. Atmos. Ocean. Sci., 21, 375-391, doi: 10.3319/TAO.2009.05.25.01(A). [Link]

Zeng, X. M., M. Zhao, B. K. Su, J. P. Tang, Y. Q. Zheng, Y. J. Zhang, and J. Chen, 2002: The effects of landsurface heterogeneities on regional climate: A sensitivity study. Meteorol. Atmos. Phys., 81, 67-83, doi: 10. 1007/s007030200031. [Link]

Zhang, J., Q. Zhang, N. Guo, and J. Wang, 2005: Retrieval of the land surface albedo over arid oasis of northwest China from EOS-MODIS. Chin. J. Atmos. Sci., 29, 510-517.

Zhang, K., J. Qu, R. Zu, and W. Ta, 2008: Characteristics of wind-blown sand on gobi/mobile sand surface. Environ. Geol., 54, 411-416, doi: 10.1007/s00254-007-08 27-2. [Link]

Zhang, Y.C., 1995: Numerical modeling of climatic effects of underlying surface change in the earth-air coupled system. J. Nanjing U. (Nat. Sci.), 31, 657-665.

Zhong, X. J., H. H. Xiong, and J. B. Zhang, 2010: Research on characteristics of micro-climate in different underlying surface in Yutian county, Xinjiang. Res. Soil Water Conserv., 17, 134-139.

Zilitinkevich, S. S. and D. V. Chalikov, 1968: On momentum heat and moisture exchange in processs of interaction between atmosphere and underlying surface. Izv. Atmos. Ocean. Phys., 4, 765. 